\title{
Calcium-permeable AMPA receptors in neonatal hypoxic-ischemic encephalopathy (Review)
}

\author{
XIAO-JUAN TANG and FENG XING \\ Department of Neonatology, Children's Hospital Affiliated to Soochow University, Suzhou, Jiangsu 215003, P.R. China
}

Received May 31, 2013; Accepted July 18, 2013

DOI: 10.3892/br.2013.154

\begin{abstract}
Hypoxic-ischemic encephalopathy (HIE) is an important cause of brain injury in the newborn and may result in long-term devastating consequences. Excessive stimulation of glutamate receptors (GluRs) is a pivotal mechanism underlying ischemia-induced selective and delayed neuronal death. Although initial studies focused on N-methyl-D-aspartic acid (NMDA) receptors as critical mediators in HIE, subsequent studies supported a more central role for $\alpha$-amino-3-hyd roxy-5-methyl-4-isoxazolepropionic acid (AMPA) receptors (AMPARs), particularly $\mathrm{Ca}^{2+}$-permeable AMPARs, in brain damage associated with hypoxia-ischemia. This study reviewedthe important role of $\mathrm{Ca}^{2+}$-permeable AMPARs in $\mathrm{HIE}$ and the future potential neuroprotective strategies associated with $\mathrm{Ca}^{2+}$-permeable AMPARs.
\end{abstract}

\section{Contents}

1. Introduction

2. Structure of $\mathrm{Ca}^{2+}$-permeable AMPARs

3. $\mathrm{Ca}^{2+}$-permeable AMPARs and glutamate excitotoxicity

4. $\mathrm{Ca}^{2+}$-permeable AMPARs and $\mathrm{Ca}^{2+}$ influx

5. $\mathrm{Ca}^{2+}$-permeable AMPARs and $\mathrm{Zn}^{2+}$ translocation

6. $\mathrm{Ca}^{2+}$-permeable AMPARs and delayed cell death

7. $\mathrm{Ca}^{2+}$-permeable AMPARs and long-term effects

8. Conclusions

Correspondence to: Professor Feng Xing, Department of Neonatology, Children's Hospital Affiliated to Soochow University, 303 Jingde Road, Suzhou, Jiangsu 215003, P.R. China

E-mail: xing_feng66@hotmail.com

Abbreviations: HIE, hypoxic-ischemic encephalopathy; AMPA, $\alpha$-amino-3-hydroxy-5-methyl-4-isoxazolepropionic acid; NMDA, N-methyl-D-aspartic acid; GluR, glutamate receptor; Naspm, 1-naphthyl acetyl spermine

Key words: hypoxic-ischemic encephalopathy, neonate, $\mathrm{Ca}^{2+}$-permeable $\alpha$-amino-3-hydroxy-5-methyl-4-isoxazolepropionic acid receptors, glutamate receptors 2

\section{Introduction}

Hypoxic-ischemic encephalopathy (HIE) is a major cause of newborn morbidity and mortality, occurring in $2 \%$ of full-term infants and in $\sim 60 \%$ of premature newborns (1). In total, $20-50 \%$ of hypoxic-ischemic infants who exhibit severe HIE, succumb to this condition during the newborn period $(2,3)$. Of the survivors of severe HIE, $\leq 25 \%$ exhibit permanent neuropsychological handicaps in the form of learning disabilities, epilepsy or cerebral palsy (4). Although the exact cause is not always identified, antecedents include cord prolapse, uterine rupture, placental abruption, placenta previa, maternal hypotension, breech presentation or shoulder dystocia (5-7). The principal mechanism underlying neurological damage in HIE is oxygen and glucose deprivation (OGD), which causes a primary energy failure and initiates a cascade of biochemical events leading to cell dysfunction and ultimately to cell death. The increase in extracellular glutamate concentration and activation of glutamate receptors (GluRs) after hypoxia-ischemia triggers the excitotoxic cascade. There is an increase in cytosolic $\mathrm{Ca}^{2+}$ via influx through open $\mathrm{N}$-methyl-D-aspartic acid (NMDA) and $\mathrm{Ca}^{2+}$-permeable $\alpha$-amino-3-hydroxy-5-methyl-4-isoxazole propionic acid (AMPA) receptor channels and release of $\mathrm{Ca}^{2+}$ from intracellular stores. The deleterious effects of increased cytosolic $\mathrm{Ca}^{2+}$ include the activation of neuronal nitric oxide synthase and the subsequent formation of nitric oxide, the generation of free radicals and the degradation of cellular lipids via activation of phospholipases, the degradation of cellular proteins via activation of proteases and of cellular DNA via activation of nucleases, as well as accentuation of mitochondrial injuries (8-11). Over the last two decades, several studies demonstrated the critical role of glutamate as the mediator of neuronal death in HIE (12-15).

Glutamate is the predominant excitatory amino acid neurotransmitter and has three major types of ionotropic receptors, NMDA, AMPA and kainate receptors, present in the majority of neurons and glial processes $(16,17)$. AMPA receptors (AMPARs) are tetrameric assemblies of the subunits GluR1-4 and are encoded by separate genes, which are differentially expressed throughout the central nervous system. AMPARs lacking the GluR2 subunit are permeable to $\mathrm{Ca}^{2+}$ (18). Considerable evidence supports the role of GluR2-lacking $\mathrm{Ca}^{2+}$-permeable AMPARs in hypoxia-ischemia-induced neuronal death $(19,20)$. Those findings provided molecular and functional evidence for the enhanced expres- 
sion of $\mathrm{Ca}^{2+}$-permeable receptors and predicted enhanced vulnerability of neurons to ambient glutamate (19-23).

This study was approved by the ethics committee of the Children's Hospital Affiliated to Soochow University.

\section{Structure of $\mathrm{Ca}^{2+}$-permeable AMPARs}

AMPARs are ionotropic GluRs that mediate the majority of fast excitatory neurotransmissions in the mammalian central nervous system. AMPARs are composed of GluR1-4 subunits in a tetraheteromeric complex, with the vast majority of AMPARs containing GluR2 subunits $(16,24)$. The lack of $\mathrm{Ca}^{2+}$ permeability in AMPARs is the result of special genetic engineering. In all AMPAR GluR1-4 subunit genes, there exists a conserved glutamine site at the second intramembrane domain that constitutes the inner face of the channel. GluR2-lacking and, thus, $\mathrm{Ca}^{2+}$-permeable AMPARs, have been detected in several brain regions and synapses and are more abundantly encountered in early developmental neurons (25-27). AMPARs exhibit the same characteristics: i) They are $\mathrm{Ca}^{2+}$-permeable; ii) the AMPARs exhibit inward rectification in the presence of the polyamine spermine, and iii) $\mathrm{Ca}^{2+}$-permeable AMPARs become selectively sensitive to inhibition by 1-naphthyl acetyl spermine (Naspm) $(21,28)$.

$\mathrm{Ca}^{2+}$ impermeability is a consequence of editing at the $\mathrm{Q} / \mathrm{R}$ site of GluR2 pre-mRNA in which a gene-encoded glutamine (Q) codon in the channel-forming intramembrane segment is changed to an arginine $(\mathrm{R})$ codon. This $\mathrm{Q} / \mathrm{R}$ editing is mediated by the enzyme adenosine deaminase. Transgenic replacement of edited GluR2, substituting an arginine in the $\mathrm{Q} / \mathrm{R}$ editing site, was shown to restore viability $(29,30)$. Although it is evident that $\mathrm{Ca}^{2+}$-permeable AMPAR upregulation occurs in ischemia, recent evidence indicated that GluR2 RNA-editing deficiencies also occur in ischemia. In a model of transient global ischemia, GluR2 RNA-editing efficiency of individual neurons at the $\mathrm{Q} / \mathrm{R}$ site in the CA1 region of the hippocampus was significantly decreased (31). This editing efficiency was closely correlated with the $\mathrm{Ca}^{2+}$-permeability of the neurons. Those experiments provided substantial evidence that GluR2 RNA editing is crucial in mediating excitotoxic neuronal death during ischemia. Consistent with this finding, knockdown of the GluR2 gene by administration of antisense oligonucleotides, even in the absence of an ischemic insult, leads to pyramidal neuron death, whereas the overexpression of $\mathrm{Ca}^{2+}$-permeable GluR2 (Q) channels in vivo promotes the ischemia-induced death of normally resistant CA3 pyramidal cells. Moreover, the overexpression of $\mathrm{Ca}^{2+}$-impermeable GluR2 (R) channels protects CA1 neurons against ischemiainduced neuronal death. Previous studies demonstrated that neonatal hypoxia-ischemia downregulated the expression of GluR2 and enhanced AMPAR-mediated $\mathrm{Ca}^{2+}$ influx in CA1 pyramidal neurons. Ischemia induced $\mathrm{Ca}^{2+}$-dependent AMPA excitatory postsynaptic currents at the CA1 synapses, which are sensitive to the $\mathrm{Ca}^{2+}$-permeable AMPAR blocker Naspm (32-35). Those findings provided molecular and functional evidence supporting the enhanced expression of $\mathrm{Ca}^{2+}$-permeable receptors at the CA1 synapses of postischemic brain and predicted enhanced vulnerability of neurons to glutamate. More importantly, an increasing number of studies have observed the dynamic occurrence of $\mathrm{Ca}^{2+}$-permeable
AMPARs and their involvement during the induction of varied forms of hypoxia-ischemia brain injury $(36,37)$.

\section{3. $\mathrm{Ca}^{2+}$-permeable AMPARs and glutamate excitotoxicity}

Glutamate ionotropic receptors normally exhibit a sequential participation in activity-dependent neuronal plasticity and neuronal excitation for normal tasks. Excitotoxicity occurs when excessive levels of extracellular neurotransmitters, particularly glutamate, overstimulate excitatory receptors. Glutamate is used by a variety of neuronal pathways, including hearing, vision, somatosensory function, learning and memory, which may account for the disruptive effect of HIE on subsequent development (38). AMPAR-mediated excitotoxicity is involved in selective motor neuron death $(36,39)$. In some culture models, motor neurons were shown to be selectively vulnerable to AMPAR agonists due to the $\mathrm{Ca}^{2+}$ influx through $\mathrm{Ca}^{2+}$-permeable AMPARs. Since the absence of GluR2 in AMPARs renders them highly permeable to $\mathrm{Ca}^{2+}$, it was hypothesized that the selective vulnerability of motor neurons is due to their relative deficiency in GluR2 (40). The AMPAR properties correlated well with each other and with the selective vulnerability of neurons, since neurons surviving an excitotoxic event exhibited characteristics similar to those of dorsal horn neurons. The presence of a GluR2 subunit renders the AMPARs impermeable to $\mathrm{Ca}^{2+}$. The approximate time of peak sensitivity of excitotoxicity in rats is 9-10 days for AMPA, corresponding to human premature and term newborn, respectively (41). The majority of principal neurons of the neonatal hippocampus express AMPARs that exhibit a low permeability to $\mathrm{Ca}^{2+}$. In these cells, an acute reduction in GluR2 expression may lead to enhanced toxicity of endogenous glutamate (42-44). Those data indicated that $\mathrm{Ca}^{2+}$-permeable AMPARs may be a major determinant of selective neuron vulnerability to excitotoxicity in vitro.

\section{4. $\mathrm{Ca}^{2+}$-permeable AMPARs and $\mathrm{Ca}^{2+}$ influx}

During the ischemic episode, the cells depolarize and exhibit an increase in intracellular $\mathrm{Ca}^{2+}$ levels. Following reperfusion, the cells appear morphologically normal, exhibit normal intracellular $\mathrm{Ca}^{2+}$ levels and are again able to generate action potentials for 24-72 $\mathrm{h}$ after the ischemic insult $(16,45)$. Ultimately, intracellular $\mathrm{Ca}^{2+}$ increases again in vulnerable neurons and cell death ensues, exhibiting a number of the hallmarks of apoptosis. Previous studies provided evidence that $\mathrm{Ca}^{2+}$-permeable AMPARs are mediators of HIE $(26,46)$. AMPAR antagonists, but not NMDA antagonists, protect against ischemic neuronal death. The relevance of this finding, however, is unclear, as protection may be the result of antagonist-induced hypothermia, rather than blockade of $\mathrm{Ca}^{2+}$-permeable AMPARs in vulnerable neurons (47). Hypoxia-ischemia has been shown to induce downregulation of GluR2 mRNA and protein expression in vulnerable neurons prior to cell death (48). In sections from postischemic animals, CA1 neurons with robust action potentials exhibited significantly enhanced AMPA-elicited increases in intracellular $\mathrm{Ca}^{2+}$ levels compared to those in cells obtained from control animals $(49,50)$. Excitatory postsynaptic currents in postischemic CA1 neurons exhibited an enhanced $\mathrm{Ca}^{2+}$-dependent 
component that appeared to be mediated by $\mathrm{Ca}^{2+}$-permeable AMPARs. Those studies provided evidence of $\mathrm{Ca}^{2+}$ influx through AMPARs in neurons programmed to die.

\section{5. $\mathrm{Ca}^{2+}$-permeable AMPARs and $\mathrm{Zn}^{2+}$ translocation}

Recent studies suggested that the synaptic release of $\mathrm{Zn}^{2+}$ and its translocation into postsynaptic neurons probably contribute to neuronal injury in neonatal HIE $(16,51)$. $\mathrm{Zn}^{2+}$ is sequestered at high concentrations in the presynaptic boutons of numerous excitatory synapses, exhibiting particularly high levels in the hippocampus. When released with neuronal activity, $\mathrm{Zn}^{2+}$ is estimated to achieve peak synaptic concentrations of several hundred micromoles per liter (52). In vivo, hypoxia-ischemia has been associated with a depletion of presynaptic $\mathrm{Zn}^{2+}$ and concomitant $\mathrm{Zn}^{2+}$ accumulation in degenerating postsynaptic neurons. Additional support for a direct injurious role for $\mathrm{Zn}^{2+}$ under these conditions was provided by the observation that extracellular $\mathrm{Zn}^{2+}$ chelators decrease the release of $\mathrm{Zn}^{2+}$ in postsynaptic neurons with resultant selective neuronal death (53-55). Since presynaptic $\mathrm{Zn}^{2+}$ is released with glutamate from excitatory terminals and appears to gain direct entry into certain postsynaptic neurons, it is reasonable to consider that $\mathrm{Zn}^{2+}$ may permeate postsynaptic glutamate-activated channels. Previous in vitro studies indicated that $\mathrm{Zn}^{2+}$ is potently neurotoxic and is able to gain entry to neurons through voltage-sensitive $\mathrm{Ca}^{2+}$ channels, NMDA receptors and $\mathrm{Ca}^{2+}$-permeable AMPARs (56). However, neurotoxicity and imaging findings suggested that, of these routes, $\mathrm{Ca}^{2+}$-permeable AMPARs exhibit the highest permeability to $\mathrm{Zn}^{2+}$ (56). Neonatal hypoxia-ischemia leads to selective and delayed neuronal cell death, particularly of the hippocampal CA1 neurons. The delayed cell death following ischemia requires an initial translocation of $\mathrm{Zn}^{2+}$, which may be mediated by $\mathrm{Ca}^{2+}$-permeable AMPARs (57). Previous studies revealed that OGD for 15 min resulted in marked reactive $\mathrm{Zn}^{2+}$ in CA1 and CA3 pyramidal neurons. Although strong $\mathrm{Zn}^{2+}$ labeling persisted if both the NMDA antagonist MK-801 and a voltage-sensitive $\mathrm{Ca}^{2+}$ channel blocker were present, the presence of the $\mathrm{Ca}^{2+}$-permeable AMPA channel blocker Naspm significantly decreased $\mathrm{Zn}^{2+}$ accumulation in the pyramidal neurons of these two subregions (58-60).

\section{6. $\mathrm{Ca}^{2+}$-permeable AMPARs and delayed cell death}

It has been established that neuronal death escalates disease progression in ischemia. AMPARs lacking GluR2 are highly permeable to $\mathrm{Ca}^{2+}$ and it was previously suggested that they may potentially contribute to $\mathrm{Ca}^{2+}$-mediated excitotoxic cell death in disease (21). Hippocampal cells normally express GluR2 and changes in the expression levels may affect the $\mathrm{Ca}^{2+}$-permeability of AMPARs (15). It was demonstrated that 24-72 $\mathrm{h}$ following an ischemic insult, the expression of the GluR2 protein is downregulated, particularly in the CA1 region of the hippocampus, where cell death is prominent $(27,30)$. The internalization of AMPARs following OGD, a model of ischemia, was shown to lead to a subsequent delivery of $\mathrm{Ca}^{2+}$-permeable AMPARs to the synapse. This process is regulated by the gene silencing transcription factor neuronal repressor element-1 silencing transcription factor (REST).
Hypoxia-ischemia increases the expression of REST in the CA1 region of the hippocampus, which in turn suppresses GluR2 gene expression. In addition, the suppression of REST expression by the use of antisense oligodeoxynucleotides was shown to increase neuronal survival $72 \mathrm{~h}$ post OGD $(21,22)$. An important unresolved issue is the source of free $\mathrm{Zn}^{2+}$ in CA1 neurons that appears long after ischemia (61). Consistent with this mechanism, exposure of neurons in culture to oxidative stress promotes the release of $\mathrm{Zn}^{2+}$ from metallothioneins and other intracellular stores, an event that may be critical to the initiation of neuronal apoptosis. It was previously suggested that $\mathrm{Ca}^{2+}$-permeable AMPARs, when in the diseased state, potentially contribute to $\mathrm{Zn}^{2+}$ accumulation, despite such receptors also being required for maintenance of synaptic plasticity (62).

\section{7. $\mathrm{Ca}^{2+}$-permeable AMPARs and long-term effects}

A central concept in the field of learning and memory is that GluRs are essential for synaptic plasticity and memory formation. Blocking by GluR1 antagonists results in a decrease in AMPAR transmission. A certain time period is required for memory reconsolidation, which is potentiated by fear conditioning $(63,64)$. This reversal in potentiation is due to the selective removal of $\mathrm{Ca}^{2+}$-permeable AMPARs, compared to complete extinction. Those findings suggested that the presence of $\mathrm{Ca}^{2+}$-permeable AMPARs renders the memory trace labile and allows full memory erasure or modification. To assess the contribution of $\mathrm{Ca}^{2+}$-permeable AMPARs to the learning process, mutant mice were engineered with a conditional genetic deletion of GluR2 in the CA1 region of the hippocampus. Electrophysiological experiments in those animals revealed a novel form of long-term potentiation that was mediated by GluR2-lacking $\mathrm{Ca}^{2+}$-permeable AMPARs. Behavioral analyses revealed that NMDAR-independent learning was normal and required the activation of $\mathrm{Ca}^{2+}$-permeable AMPARs. Those results suggested that GluR2-lacking AMPARs play a functional and previously unidentified role in learning $(65,66)$.

\section{Conclusions}

HIE is one of the most serious birth complications affecting infants. The evidence reviewed above demonstrates overexpression of $\mathrm{Ca}^{2+}$-permeable AMPARs during the early stages of hypoxic-ischemic brain damage, suggesting an important role for $\mathrm{Ca}^{2+}$-permeable AMPAR-dependent signaling in HIE. The expression of $\mathrm{Ca}^{2+}$-permeable AMPARs may be crucial for temporal precision of signaling and is also a necessary measure to avoid neuronal excitotoxicity resulting from an overload of AMPAR-gated $\mathrm{Ca}^{2+}$ influx, $\mathrm{Zn}^{2+}$ accumulation, apoptosis and autophagy, which constitute critical steps in the pathology of ischemia-induced neuronal death. Therefore, our final aim is an individualized strategy regarding $\mathrm{Ca}^{2+}$-permeable AMPARs for neuroprotection against perinatal hypoxic-ischemic insults.

\section{Acknowledgements}

This study was supported by grants from the National Natural Science Foundation of China (nos. 81271378, 30470555 and 
30870808), the Medical Science and Technology Development Fund of Jiangsu Provincial (no. Z200118) and the Social Development Science and Technology Project of the city of Suzhou (no. SSZ0230).

\section{References}

1. Lai MC and Yang SN: Perinatal hypoxic-ischemic encephalopathy. J Biomed Biotechnol 2011: 609813, 2011.

2. Shankaran S: Neonatal encephalopathy: treatment with hypothermia. J Neurotrauma 26: 437-443, 2009.

3. Fatemi A, Wilson MA and Johnston MV: Hypoxic-ischemic encephalopathy in the term infant. Clin Perinatol 36: 835-858, 2009.

4. Martinez-Biarge M, Diez-Sebastian J, Kapellou O, et al: Predicting motor outcome and death in term hypoxic-ischemic encephalopathy. Neurology 76: 2055-2061, 2011.

5. Allen KA and Brandon DH: Hypoxic ischemic encephalopathy: pathophysiology and experimental treatments. Newborn Infant Nurs Rev 11: 125-133, 2011.

6. Thornton C, Rousset CI, Kichev A, et al: Molecular mechanisms of neonatal brain injury. Neurol Res Int 2012: 506320, 2012.

7. Kwon JM, Guillet R, Shankaran S, et al: Clinical seizures in neonatal hypoxic-ischemic encephalopathy have no independent impact on neurodevelopmental outcome: secondary analyses of data from the neonatal research network hypothermia trial. J Child Neurol 26: 322-328, 2011.

8. Douglas-Escobar $M$ and Weiss MD: Biomarkers of hypoxic-ischemic encephalopathy in newborns. Front Neurol 3 : $144,2012$.

9. Adhami F,Liao G,Morozov YM, et al: Cerebral ischemia-hypoxia induces intravascular coagulation and autophagy. Am J Pathol 169: 566-583, 2006.

10. Sameshima $H$ and Ikenoue T: Hypoxic-ischemic neonatal encephalopathy: animal experiments for neuroprotective therapies. Stroke Res Treat 2013: 659374, 2013.

11. Ghotbi N and Najibi B: Measurement of the urinary lactate/creatinine ratio for early diagnosis of the hypoxic-ischemic encephalopathy in newborns. Iran J Pediatr 20: 35-40, 2010.

12. Jenkins DD, Rollins LG, Perkel JK, et al: Serum cytokines in a clinical trial of hypothermia for neonatal hypoxic-ischemic encephalopathy. J Cereb Blood Flow Metab 32: 1888-1896, 2012

13. Shankaran S, Pappas A, McDonald SA, et al: Childhood outcomes after hypothermia for neonatal encephalopathy. N Engl J Med 366: 2085-2092, 2012.

14. Walsh BH, Broadhurst DI, Mandal R, et al: The metabolomic profile of umbilical cord blood in neonatal hypoxic ischaemic encephalopathy. PLoS One 7: e50520, 2012.

15. Liu X, Tooley J, Loberg EM, et al: Immediate hypothermia reduces cardiac troponin I after hypoxic-ischemic encephalopathy in newborn pigs. Pediatric Res 70: 352-356, 2011.

16. Liu SJ and Savtchouk I: $\mathrm{Ca}^{2+}$ permeable AMPA receptors switch allegiances: mechanisms and consequences. J Physiol 590: 13-20, 2012

17. Diamond JS: Calcium-permeable AMPA receptors in the retina Front Mol Neurosci 4: 27, 2011.

18. Man HY: GluA2-lacking, calcium-permeable AMPA receptors - inducers of plasticity? Curr Opin Neurobiol 21: 291-298, 2011

19. Rossi B, Maton G and Collin T: Calcium-permeable presynaptic AMPA receptors in cerebellar molecular layer interneurones. J Physiol 586: 5129-5145, 2008.

20. Deng W, Rosenberg PA, Volpe JJ, et al: Calcium-permeable AMPA/kainate receptors mediate toxicity and preconditioning by oxygen-glucose deprivation in oligodendrocyte precursors. Proc Natl Acad Sci USA 100: 6801-6806, 2003.

21. Noh KM, Yokota H, Mashiko T, et al: Blockade of calcium-permeable AMPA receptors protects hippocampal neurons against global ischemia-induced death. Proc Natl Acad Sci USA 102: 12230-12235, 2005.

22. Yin HZ, Sensi SL, Ogoshi F and Weiss JH: Blockade of $\mathrm{Ca}^{2+}$-permeable AMPA/kainate channels decreases oxygen-glucose deprivation-induced $\mathrm{Zn}^{2+}$ accumulation and neuronal loss in hippocampal pyramidal neurons. J Neurosci 22: 1273-1279, 2002.

23. Weiss JH: Ca permeable AMPA channels in diseases of the nervous system. Front Mol Neurosci 4: 42, 2011.
24. Gainey MA, Hurvitz-Wolff JR, Lambo ME, et al: Synaptic scaling requires the GluR2 subunit of the AMPA receptor. J Neurosci 29: 6479-6489, 2009.

25. Gryder DS, Castaneda DC and Rogawski MA: Evidence for low GluR2 AMPA receptor subunit expression at synapses in the rat basolateral amygdala. J Neurochem 94: 1728-1738, 2005.

26. Li DP, Byan HS and Pan HL: Switch to glutamate receptor 2-lacking AMPA receptors increases neuronal excitability in hypothalamus and sympathetic drive in hypertension. J Neurosci 32: 372-380, 2012

27. Oguro K, Oguro N, Kojima T, et al: Knockdown of AMPA receptor GluR2 expression causes delayed neurodegeneration and increases damage by sublethal ischemia in hippocampal CA1 and CA3 neurons. J Neurosci 19: 9218-9227, 1999.

28. Van Damme P, Van Den Bosch L, Van Houtte E, et al: GluR2-dependent properties of AMPA receptors determine the selective vulnerability of motor neurons to excitotoxicity. J Neurophysiol 88: 1279-1287, 2002

29. Midgett CR, Gill A and Madden DR: Domain architecture of a calcium-permeable AMPA receptor in a ligand-free conformation. Front Mol Neurosci 4: 56, 2012.

30. Wright A and Vissel B: The essential role of AMPA receptor GluR2 subunit RNA editing in the normal and diseased brain. Front Mol Neurosci 5: 34, 2012.

31. Yang Y, Wang XB and Zhou Q: Perisynaptic GluR2-lacking AMPA receptors control the reversibility of synaptic and spines modifications. Proc Natl Acad Sci USA 107: 11999-12004, 2010.

32. Isa T, Itazawa S, Ino M, Tsuzuki K and Ozawa S: Distribution of neurones expressing inwardly rectifying and $\mathrm{Ca}^{2+}$-permeable AMPA receptors in rat hippocampal slices. J Physiol 491 (Pt 3): 719-733, 1996.

33. Colbourne F, Grooms SY, Zukin RS, et al: Hypothermia rescues hippocampal CA1 neurons and attenuates down-regulation of the AMPA receptor GluR2 subunit after forebrain ischemia. Proc Natl Acad Sci USA 100: 2906-2910, 2003.

34. Grooms SY, Opitz T, Bennett MV, et al: Status epilepticus decreases glutamate receptor $2 \mathrm{mRNA}$ and protein expression in hippocampal pyramidal cells before neuronal death. Proc Natl Acad Sci USA 97: 3631-3636, 2000.

35. Rozov A, Sprengel R and Seeburg PH: GluA2-lacking AMPA receptors in hippocampal CA1 cell synapses: evidence from gene-targeted mice. Front Mol Neurosci 5: 22, 2012.

36. Zaitsev AV, Kim KK, Fedorova IM, et al: Specific mechanism of use-dependent channel block of calcium-permeable AMPA receptors provides activity-dependent inhibition of glutamatergic neurotransmission. J Physiol 589: 1587-1601, 2011.

37. Talos DM, Follett PL, Folkerth RD, et al: Developmental regulation of $\alpha$-amino-3-hydroxy-5-methyl-4-isoxazole-propionic acid receptor subunit expression in forebrain and relationship to regional susceptibility to hypoxic/ischemic injury. II. Human cerebral white matter and cortex. J Comp Neurol 497: 61-77, 2006.

38. Spaethling JM, Klein DM, Singh $\mathrm{P}$ and Meaney DF: Calcium-permeable AMPA receptors appear in cortical neurons after traumatic mechanical injury and contribute to neuronal fate. J Neurotrauma 25: 1207-1216, 2008.

39. Nguyen V and McQuillen PS: AMPA and metabotropic excitoxicity explain subplate neuron vulnerability. Neurobiol Dis 37: 195-207, 2010.

40. Mahajan SS, Thai KH, Chen K, et al: Exposure of neurons to excitotoxic levels of glutamate induces cleavage of the RNA editing enzyme, adenosine deaminase acting on RNA 2, and loss of GLUR2 editing. Neuroscience 189: 305-315, 2011.

41. Mahajan SS and Ziff EB: Novel toxicity of the unedited GluR2 AMPA receptor subunit dependent on surface trafficking and increased $\mathrm{Ca}^{2+}$-permeability. Mol Cell Neurosci 35: 470-481, 2007.

42. Sanderson JL, Gorski JA, Gibson ES, et al: AKAP150-anchored calcineurin regulates synaptic plasticity by limiting synaptic incorporation of $\mathrm{Ca}^{2+}$-permeable AMPA receptors. J Neurosci 32: 15036-15052, 2012.

43. Tanaka H, Calderone A, Jover T, et al: Ischemic preconditioning acts upstream of GluR2 down-regulation to afford neuroprotection in the hippocampal CA1. Proc Natl Acad Sci USA 99: 2362-2367, 2002 .

44. Zonouzi M, Renzi M, Farrant M and Cull-Candy SG: Bidirectional plasticity of calcium-permeable AMPA receptors in oligodendrocyte lineage cells. Nat Neurosci 14: 1430-1438, 2011. 
45. Robertson SJ, Burnashev $\mathrm{N}$ and Edwards FA: $\mathrm{Ca}^{2+}$ permeability and kinetics of glutamate receptors in rat medial habenula neurones: implications for purinergic transmission in this nucleus. J Physiol 518: 539-549, 1999.

46. Johnson FO, Yuan Y, Hajela RK, et al: Exposure to an environmental neurotoxicant hastens the onset of amyotrophic lateral sclerosis-like phenotype in human $\mathrm{Cu}^{2+} / \mathrm{Zn}^{2+}$ superoxide dismutase 1 G93A mice: glutamate-mediated excitotoxicity. J Pharmacol Exp Ther 338: 518-527, 2011.

47. Oren I, Nissen W, Kullmann DM, et al: Role of ionotropic glutamate receptors in long-term potentiation in rat hippocampal CA1 oriens-lacunosum moleculare interneurons. J Neurosci 29: 939-950, 2009.

48. Vieira M, Fernandes J, Burgeiro A, et al: Excitotoxicity through $\mathrm{Ca}^{2+}$-permeable AMPA receptors requires $\mathrm{Ca}^{2+}$-dependent JNK activation. Neurobiol Dis 40: 645-655, 2010.

49. Oh MC, Kim JM, Safaee M, et al: Overexpression of calcium-permeable glutamate receptors in glioblastoma derived brain tumor initiating cells. PLoS One 7: e47846, 2012.

50. Xu TL, Li JS, Jin YH, et al: Modulation of the glycine response by $\mathrm{Ca}^{2+}$-permeable AMPA receptors in rat spinal neurones. J Physiol 514: 701-711, 1999.

51. Carter RE, Weiss JH and Shuttleworth CW: $\mathrm{Zn}^{2+}$ chelation improves recovery by delaying spreading depression-like events. Neuroreport 21: 1060-1064, 2010.

52. Watt NT, Taylor DR, Kerrigan TL, et al: Prion protein facilitates uptake of zinc into neuronal cells. Nat Commun 3: 1134, 2012.

53. Ma J and Lowe G: Calcium permeable AMPA receptors and autoreceptors in external tufted cells of rat olfactory bulb. Neuroscience 144: 1094-1108, 2007.

54. Deshpande LS, Limbrick DD, Sombati S, et al: Activation of a novel injury-induced calcium-permeable channel that plays a key role in causing extended neuronal depolarization and initiating neuronal death in excitotoxic neuronal injury. J Pharmacol Exp Ther 322: 443-452, 2007.

55. Li MH, Inoue K, Si HF and Xiong ZG: Calcium-permeable ion channels involved in glutamate receptor-independent ischemic brain injury. Acta Pharmacol Sin 32: 734-740, 2011.
56. Jia Y, Jeng JM, Sensi SL, et al: $\mathrm{Zn}^{2+}$ currents are mediated by calcium-permeable AMPA/kainate channels in cultured murine hippocampal neurones. J Physiol 543: 35-48, 2002.

57. Deniro M and Al-Mohanna FA: Zinc transporter 8 (ZnT8) expression is reduced by ischemic insults: a potential therapeutic target to prevent ischemic retinopathy. PLoS One 7: e50360, 2012.

58. Takeda A, Takada S, Nakamura M, et al: Transient increase in $\mathrm{Zn}^{2+}$ in hippocampal CA1 pyramidal neurons causes reversible memory deficit. PLoS One 6: e28615, 2011.

59. Waters DJ and Allen TG: $\mathrm{Ca}^{2+}$-permeable non-NMDA glutamate receptors in rat magnocellular basal forebrain neurones. J Physiol 508: 453-469, 1998.

60. Evstratova A and Toth K: Synaptically evoked $\mathrm{Ca}^{2+}$ release from intracellular stores is not influenced by vesicular zinc in CA3 hippocampal pyramidal neurones. J Physiol 589: 5677-5689, 2011.

61. Cho IH, Im JY, Kim D, et al: Protective effects of extracellular glutathione against $\mathrm{Zn}^{2+}$-induced cell death in vitro and in vivo. J Neurosci Res 74: 736-743, 2003.

62. Medvedeva YV, Lin B, Shuttleworth $\mathrm{CW}$ and Weiss JH: Intracellular $\mathrm{Zn}^{2+}$ accumulation contributes to synaptic failure, mitochondrial depolarization, and cell death in an acute slice oxygen-glucose deprivation model of ischemia. J Neurosci 29: 1105-1114, 2009.

63. Kwak S and Weiss JH: Calcium-permeable AMPA channels in neurodegenerative disease and ischemia. Curr Opin Neurobiol 16: 281-287, 2006.

64. Clem RL and Huganir RL: Calcium-permeable AMPA receptor dynamics mediate fear memory erasure. Science 330: 1108-1112, 2010.

65. WiltgenBJ,Royle GA,GrayEE, etal: Arole for calcium-permeable AMPA receptors in synaptic plasticity and learning. PLoS One 5: e12818, 2010

66. Shepherd JD: Memory, plasticity and sleep - a role for calcium permeable AMPA receptors? Front Mol Neurosci 5: 49, 2012. 